\title{
Fire management in Mediterranean-climate shrublands: a case study from the Cape fynbos, South Africa
}

\author{
Brian W. van Wilgen*,1, Gregory G. Forsyth ${ }^{1}$, Helen de Klerk ${ }^{2}$, Sonali Das ${ }^{3}$, \\ Sibusisiwe Khuluse ${ }^{3}$ and Peter Schmitz ${ }^{3}$ \\ ${ }^{1}$ Centre for Invasion Biology, CSIR Natural Resources and the Environment, P.O. Box 320, Stellenbosch 7599, South \\ Africa; ${ }^{2}$ Scientific Services, Western Cape Nature Conservation Board, Private Bag X5014, Stellenbosch 7599, South \\ Africa; and ${ }^{3}$ CSIR Built Environment, P.O. Box 395, Pretoria 0001, South Africa
}

\begin{abstract}
Summary
1. Fire is an important process in Mediterranean-ecosystem shrublands, and prescribed burning is often used to manage these ecosystems. Analyses of past fire regimes are required to interpret biotic responses to fire, as well as to assess the degree to which management interventions have been able to influence the fire regime.

2. We used a spatial data base of fires within 10 protected areas covering $>720000$ ha to examine the frequency, seasonality, size and cause of fires over four decades. Our study covered five fire climate zones and a range of mountain fynbos shrubland types. We examined whether regular prescribed burning would be necessary to rejuvenate the vegetation, and also to reduce the incidence and extent of wildfires.

3. Cumulative fire frequency distributions indicated that the probability of fire was not strongly affected by post-fire age, with $50 \%$ of the area experiencing a successive fire within 10-13 years after the previous fire in most areas. This suggests that the accumulation of fuel did not limit the occurrence of wildfires, and that regular prescribed burning would not necessarily reduce the risk of wildfires.

4. Inland zones experienced more severe fire weather than coastal zones ( $~ 35 \%$ vs. $11-19 \%$ of days with high to very high fire danger, respectively). Despite these differences, fire return periods were similar (10-13 years), suggesting that the availability of ignitions, and not fuel or weather, limited the occurrence of wildfires.

5. Despite a policy that promoted prescribed burning, a relatively small area (between $4 \cdot 6 \%$ and $32.4 \%$ of the area of all fires) burned in prescribed burns. Seasonal restrictions for safety and ecological reasons, the imperative to integrate planned fires with invasive alien plant treatments and unplanned wildfires have all contributed to the relatively small area that burnt in prescribed burns. 6. Synthesis and applications. Recurrent wildfires, and not prescribed burning, are providing sufficient opportunities for fire-stimulated regeneration in fynbos ecosystems. Because of this, and because burning to reduce fuel loads is unlikely to prevent wildfires, there should be less pressure to conduct prescribed burning. The predicted growth in human populations in all areas is expected to increase the number of ignition opportunities and the frequency of fires, with detrimental consequences for biodiversity conservation and the control of invasive alien trees. Fire frequency should thus be monitored and steps should be taken to protect areas that burn too frequently.
\end{abstract}

Key-words: biodiversity conservation, fire frequency, fire season, invasive alien plants, pines, prescribed burning 


\section{Introduction}

Fire is an important ecological process in many of the world's ecosystems, where it regularly removes much of the aboveground biomass, and creates the conditions necessary for reproduction and coexistence in plant communities (Bond \& Keeley 2005). In fire-prone ecosystems, the range of fire season, frequency (return period), size and intensity of fires combine to produce a fire regime (Gill 1975) that characterizes the ecosystem. Within such ecosystems, the component biota is adapted to, and in many cases dependent on, particular fire regimes (Bond \& van Wilgen 1996). Where fire-prone natural landscapes have become fragmented due to development, fires can also pose a significant threat to infrastructure, crops, livestock and humans. Managers of many of the world's fire-prone ecosystems thus face the problem of reducing the risk of damaging wildfires, while simultaneously ensuring that fire continues to play its vital role in maintaining healthy ecosystems (Biswell 1989; Keith, Williams \& Woinarski 2002; Keeley \& Fotheringham 2006).

In fire-prone ecosystems, individual fire events contribute to the fire regime over time. Managers usually seek to promote a particular regime by burning a selected proportion of the land in a given season, and at the appropriate return interval. They will also respond to wildfires that threaten life or property, or that may be ecologically undesirable, by attempting to suppress or contain them. The immediate focus of managers on any given fire suggests that their actions are event-driven (Gill, Bradstock \& Williams 2002). The response of ecosystems, however, depends not only on the effects of a single fire, but also on the legacies inherited from previous fires. Moving beyond the management of fires as isolated events, and towards the concept of managing fire regimes, will require a far better understanding of whether and how fire regimes can be influenced (Gill et al. 2002). This understanding, in turn, can only be gained if long-term fire records are available, and if they have been adequately analysed and interpreted. Such detailed understanding is often absent, and fire managers can only respond to the 'visible mosaic' (the footprint left by the last fire, Parr \& Andersen 2006); the 'invisible mosaic' (the patterns of all other past fires) does not normally influence their actions. Quantifying fire regimes is a fundamental first step towards sound ecosystem fire management, and provides a background to the interpretation of biotic responses to fire. The degree to which management interventions impact on fire regimes is an another important aspect of fire management (van Wilgen et al. 2004), but is rarely reported.

Mediterranean-type ecosystems share several characteristics with regard to fire and its management. These regions around the Mediterranean basin, California, south-western Australia and parts of South Africa have warm, dry summers and fireprone vegetation that promotes the regular occurrence of fires. In addition, all have growing human populations whose presence will complicate fire management. The fynbos shrublands of the Mediterranean-climate regions of South Africa provide an example of a fire-prone and fire-adapted ecosystem that is managed for conservation purposes using prescribed burning
(Richardson et al. 1994). These shrublands are noted for their diversity and species-richness (Cowling, Richardson \& Mustart 1997), and policy calls for them to be burned at 12-15 year intervals in late summer or early autumn (van Wilgen, Bond \& Richardson 1992). The prescribed burning policy replaced one of the fire suppressions in 1968, and had the dual goals of rejuvenating the vegetation by ensuring that regular fires took place, and of reducing the risk of large wildfires by reducing and fragmenting fuel loads (Van Wilgen 2009). Recently, agencies charged with the management of fynbos areas have made a concerted effort to build spatially explicit fire data bases (De Klerk 2008; Forsyth \& van Wilgen 2008). These data bases provide information on the occurrence of fires in fynbos protected areas over four or more decades, and can be used to quantify elements of the fire regimes that have prevailed under a management policy that promoted judicious prescribed burning.

In this paper, we report on an analysis of the fire regimes in 10 fynbos protected areas, over the past four decades. Our goals were (i) to quantify the elements of the fire regime and the factors that influenced it; (ii) to assess the degree to which prescribed burning influenced the fire regimes; and (iii) to examine whether or not the goals of prescribed burning had been realized. In particular, we examined whether burning would be necessary to regularly rejuvenate the vegetation, and whether regular burning would reduce the incidence and extent of wildfires.

\section{Materials and methods}

\section{STUDY AREAS AND FIRE MANAGEMENT}

Our study focussed on 10 fynbos-protected areas that collectively cover 726180 ha (Table 1). Most are mountainous areas that range in altitude from sea level to $2000 \mathrm{~m}$ a.s.l. Mean annual rainfall is variable; data in Table 1 are from Smithers \& Schulze (2000), but as a general rule rainfall increases with altitude. In the western half of the fynbos biome, rain falls predominantly in the winter months (from May to September); the seasonal distribution of rainfall becomes bimodal (with peaks in March and September) in the eastern part of the biome. These shifts in rainfall seasonality also affect the seasonality of fires, and the fynbos biome has been subdivided into five fire climate zones (Table 2) that provide useful subdivisions for the purposes of examining fire regimes and their effects (van Wilgen 1984).

Mucina \& Rutherford (2006) recognized 81 distinct fynbos vegetation units, and 38 renosterveld and strandveld (coastal) units, within the fynbos biome. The protected areas in our analysis included predominantly fynbos vegetation units in mountain areas. The lowland areas of the fynbos biome are largely transformed and consist mainly of renosterveld and strandveld units. The biome's vegetation has high levels of endemism, with over $6200(69 \%)$ of the $\sim 9000$ plant species being endemic to the biome (Goldblatt \& Manning 2002). Structurally, the vegetation comprises finely divided shrubs and graminiod plants that form a coarse fuel bed (van Wilgen \& van Hensbergen 1992). Invasive alien plants are found in all areas, with estimated cover (after Le Maitre, Versfeld \& Chapman 2000) varying between $0 \cdot 2 \%$ and $14 \%$ (Table 1). The major invasive species include Australian acacias (Acacia mearnsii, Acacia cyclops, Acacia saligna and Acacia melanoxylon), hakeas (Hakea sericea and Hakea gibbosa) and 
Table 1. Salient features of 10 protected areas in the fynbos biome, South Africa

\begin{tabular}{|c|c|c|c|c|c|c|}
\hline Protected area & Fire climate zone & Centre point & Area (ha) & $\begin{array}{l}\text { Length of } \\
\text { fire record }\end{array}$ & $\begin{array}{l}\text { Mean annual } \\
\text { rainfall } \\
\text { (range, mm) }\end{array}$ & $\begin{array}{l}\text { Invaded } \\
\text { area }(\% \text { cover } \\
\text { in protected } \\
\text { area) }\end{array}$ \\
\hline Table Mountain National Park* & Western coastal & $34^{\circ} 09^{\prime} \mathrm{S} ; 18^{\circ} 23^{\prime} \mathrm{E}$ & 26554 & 1970-2007 & $400-1700$ & $7 \cdot 7$ \\
\hline Kogelberg Nature Reserve* & Western coastal & $34^{\circ} 16^{\prime} \mathrm{S} ; 18^{\circ} 56^{\prime} \mathrm{E}$ & 37851 & 1970-2007 & $700-1100$ & $1 \cdot 8$ \\
\hline Riviersonderend Nature Reserve & Southwest coastal & $34^{\circ} 00^{\prime} \mathrm{S} ; 19^{\circ} 34^{\prime} \mathrm{E}$ & 69046 & 1970-2007 & $590-600$ & $7 \cdot 1$ \\
\hline Nuweberg Nature Reserve & Western inland & $34^{\circ} 07^{\prime} \mathrm{S} ; 19^{\circ} 08^{\prime} \mathrm{E}$ & 59936 & 1972-2007 & $700-780$ & $10 \cdot 7$ \\
\hline Waterval Nature Reserve & Western inland & $33^{\circ} 21^{\prime} \mathrm{S} ; 19^{\circ} 05^{\prime} \mathrm{E}$ & 108055 & 1974-2007 & $420-440$ & $2 \cdot 1$ \\
\hline Limietberg Nature Reserve & Western inland & $33^{\circ} 31^{\prime} \mathrm{S} ; 19^{\circ} 09^{\prime} \mathrm{E}$ & 90044 & $1970-2005$ & $530-570$ & $14 \cdot 0$ \\
\hline Cedarberg Nature Reserve* & Western inland & $32^{\circ} 30^{\prime} \mathrm{S} ; 19^{\circ} 00^{\prime} \mathrm{E}$ & 122735 & 1970-2006 & $650-950$ & $1 \cdot 2$ \\
\hline Outeniqua Nature Reserve & Eastern coastal & $33^{\circ} 52^{\prime} \mathrm{S} ; 22^{\circ} 36^{\prime} \mathrm{E}$ & 41962 & 1970-2006 & $280-620$ & $9 \cdot 1$ \\
\hline Kamanassie Nature Reserve & Eastern inland & $33^{\circ} 35^{\prime} \mathrm{S} ; 22^{\circ} 51^{\prime} \mathrm{E}$ & 49591 & 1970-2006 & $300-700$ & $3 \cdot 2$ \\
\hline Swartberg Nature Reserve* & Eastern inland & $33^{\circ} 21^{\prime} \mathrm{S} ; 22^{\circ} 19^{\prime} \mathrm{E}$ & 120416 & 1970-2006 & $100-1000$ & $0 \cdot 2$ \\
\hline
\end{tabular}

*Protected areas that are also World Heritage Sites. See Table 2 for fire climate zone descriptions.

Table 2. Features of five fire climate zones (after van Wilgen 1984) in the fynbos biome, South Africa

\begin{tabular}{|c|c|c|}
\hline Fire climate zone & Location & Features \\
\hline Western coastal & $\begin{array}{l}\text { West coast, from } 32^{\circ} 30^{\prime} \mathrm{S} \text { to } \\
34^{\circ} 09^{\prime} \mathrm{S}\end{array}$ & $\begin{array}{l}\text { Seasonal variation in fire potential (high in summer and low in winter). } \\
\text { Fires most likely under occasional, extreme conditions }\end{array}$ \\
\hline Western inland & $\begin{array}{l}\text { Western inland areas from } 32^{\circ} 30^{\prime} \\
\mathrm{S} \text { to } 33^{\circ} 30^{\prime} \mathrm{S} \text {, and extending } \\
\text { eastwards to } 19^{\circ} 30^{\prime} \mathrm{E}\end{array}$ & $\begin{array}{l}\text { Strong seasonal variation in fire potential (high in summer and low in } \\
\text { winter) }\end{array}$ \\
\hline Southwest coastal & $\begin{array}{l}\text { Southern coastal areas from } \\
19^{\circ} \mathrm{E} \text { to } 22^{\circ} \mathrm{E}\end{array}$ & $\begin{array}{l}\text { Fire potential highest in summer but mean fire potential not strongly } \\
\text { seasonal. Fires most likely under extreme conditions in summer, but winter } \\
\text { fires associated with hot, dry winds occur occasionally }\end{array}$ \\
\hline Eastern coastal & $\begin{array}{l}\text { Southern coastal areas from } \\
22^{\circ} \mathrm{E} \text { to } 26^{\circ} \mathrm{E}\end{array}$ & $\begin{array}{l}\text { The annual fire-potential cycle is bimodal (more markedly so in the east } \\
\text { than in the west), with fires experienced under occasional suitable } \\
\text { conditions in both winter and summer }\end{array}$ \\
\hline Eastern inland & $\begin{array}{l}\text { Eastern inland areas between } \\
19^{\circ} 30^{\prime} \mathrm{E} \text { and } 26^{\circ} 00^{\prime} \mathrm{E}\end{array}$ & $\begin{array}{l}\text { The zone experiences a shift from winter-dominated to summer-dominated } \\
\text { rainfall from west to east. High evapo-transpiration in summer effectively } \\
\text { means that fire potential remains greatest in summer }\end{array}$ \\
\hline
\end{tabular}

pines (Pinus pinaster and Pinus radiata). The presence of invasive alien vegetation can complicate fire management, as these species are also fire-adapted and require treatment before the areas can be burnt (Richardson et al. 1994; Holmes et al. 2000). A detailed account of the evolution of fire and invasive alien plant management in fynbos is provided by Van Wilgen (2009).

\section{FIRE HISTORY DATA BASE}

Fires in all protected areas have been recorded by managers for many decades. However, as earlier records were less reliable, we confined our analysis to records as far back as 1970, where available (Table 1). Typical fire records included a mapped boundary of each fire, along with the dates on which the fire occurred. Causes of fires were recorded in most cases; in this analysis, we distinguished only between prescribed burns and all other fires. We assembled these records and captured the boundaries of all fires on a geographic information system. Records were checked for completeness, and a concerted effort was made to locate missing records.

\section{FUEL ACCUMULATION AND THE PROBABILITY OF FIRE}

One of the goals of prescribed burning was to reduce fuel loads that accumulate between fires, with the aim of reducing the risk of wildfires. We tested the assumption that fire hazard increases with post-fire age by deriving hazard functions that fit a flexible, generalized Weibull model to fire interval probability distributions (Moritz et al. 2004). The function is expressed as $\lambda(t)=c t^{c-1} / b^{c}$, where $\lambda(t)$ is the hazard of burning, $b$ is a scale parameter related to the expected interval between fires and $c$ is a shape parameter that captures how the hazard of burning changes with the time since the last fire $(t)$. Where $c=1$, the hazard does not change with time since fire; for values of $c$ between 1 and 2, fire hazard grows at a diminishing rate, while $c>2$ indicates an exponential increase in hazard with time since the last fire. To assess fire return intervals, we delimited areas of unique fire history by overlaying fire records for each protected area. Our analysis accounted for censored values (Polakow \& Dunne 1999), where fire return intervals prior to the first fire on record, and following the last fire on record cannot be known.

\section{FREQUENCY, SEASON AND SIZE OF FIRES}

Fire return intervals vary at the same point between successive fires, but an estimate of the typical return interval that characterizes a particular area is useful for the purpose of comparing the relative frequency of fires between areas. The probability distributions described above were used to estimate a median fire return interval for each of the protected areas, using the estimate at which the proportion of the area surviving without a successive fire is 0.5 in the generalized 
Weibull model. These estimations accounted for censored values (Polakow \& Dunne 1999).

We examined the seasonal distribution of fires in each of the five fire climate zones. In addition, we determined the total area of fires in different size classes, as follows: $<1,1-10,10-100,100-1000,1000$ 10000 and $>10000$ ha. We included the extent of the fires within the boundaries of the protected areas only. Fire records sometimes showed that individual fires burned beyond the boundaries of the protected areas, but as these fires were not consistently recorded, they were not included in the analysis.

We obtained daily weather data from a weather recording station in each of the five fire climate zones (Table 2) in the fynbos biome. We used the McArthur Forest Fire Danger Index (Noble, Gill \& Bary 1980) to calculate daily indices of fire danger. The data used included daily maximum temperature and minimum relative humidity, wind speed, the time since last rain fell, and moisture deficit to estimate a fire danger index (FDI). FDI values of 0-5 are considered low, 5-12

Table 3. Parameters of a generalized Weibull model of fire hazard as a function of post-fire age in 10 protected areas in the fynbos biome

\begin{tabular}{|c|c|c|}
\hline Protected area & Scale parameter, $b$ & Shape parameter, \\
\hline Table Mountain & $15 \cdot 80(15 \cdot 45-16 \cdot 15)$ & $1.22(1.19-1.24)$ \\
\hline Kogelberg & $20 \cdot 40(19 \cdot 67-21 \cdot 14)$ & $1.47(1.42-1.53)$ \\
\hline Riviersonderend & $12 \cdot 22(11 \cdot 88-12 \cdot 58)$ & $1.52(1.47-1.57)$ \\
\hline Nuweberg & $13 \cdot 78(13 \cdot 31-14 \cdot 26)$ & $1.21(1.18-1.26)$ \\
\hline Waterval & $14 \cdot 01(13 \cdot 59-14 \cdot 44)$ & $1.50(1.44-1.55)$ \\
\hline Limietberg & $12 \cdot 50(12 \cdot 25-12 \cdot 76)$ & $1.37(1.34-1.40)$ \\
\hline Cedarberg & $16 \cdot 66(16 \cdot 32-17 \cdot 00)$ & $1.39(1.36-1.42)$ \\
\hline Outeniqua & $22.38(21.93-22.85)$ & $1.5(1.47-1.54)$ \\
\hline Kamanassie & $13 \cdot 37(12 \cdot 82-13 \cdot 94)$ & $1.48(1.41-1.55)$ \\
\hline Swartberg & $27 \cdot 39(26 \cdot 68-29 \cdot 12)$ & $1.29(1.26-1.33)$ \\
\hline
\end{tabular}

Numbers in parentheses are the $95 \%$ confidence limits. moderate, 13-24 high, 25-50 very high, and $>50$ extreme. Each fire on record was assigned a FDI; where a fire burnt over more than 1 day, the highest FDI during the fire was used to represent weather during the fire.

\section{Results}

\section{FUEL ACCUMULATION AND THE PROBABILITY OF FIRE}

The shape parameter $(c)$ for the Weibull model for all 10 protected areas was between 1 and 2 (Table 3). A value of $c=1$ indicates that fire hazard does not change with increasing postfire age; a value of 2 indicates a linear increase, and values $>2$ indicate increasingly exponential growth in fire hazard with post-fire age (Moritz et al. 2004). Values of $1<c<2$ suggest that fire hazard does grow with post-fire age, but at a diminishing rate; in other words, the probability of fire increases with post-fire age for the first few years post-fire, after which postfire age has a lesser effect on the probability of fire. Cumulative fire frequency distributions indicate that the probability of fire in fynbos was generally not strongly affected by post-fire age (Fig. 1). Rather than exhibiting a sigmoidal shape (where the distributions would show relatively flat slopes in the initial years after fire, and much steeper slopes thereafter), the distributions show steep declines in the initial decade after a fire (Fig. 1).

\section{PRESCRIBED BURNING AND FIRE RETURN INTERVALS}

A total of 1689 fires burning over 1.3 million ha occurred in the 10 protected areas over the past 33-37 years (Table 4).
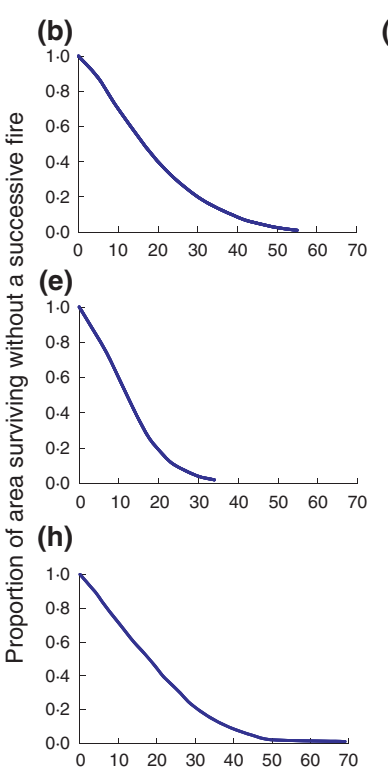

(a)

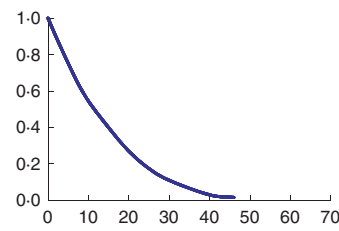

(c)

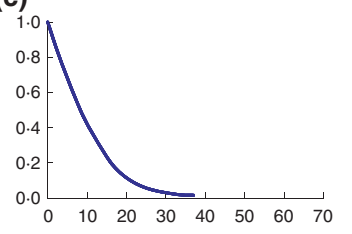

(f)

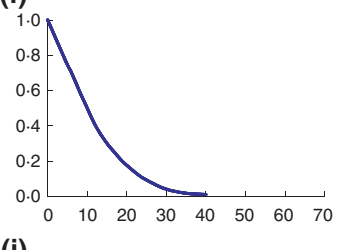

(i)

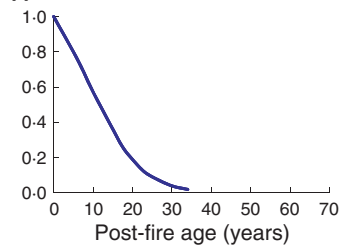

(d)

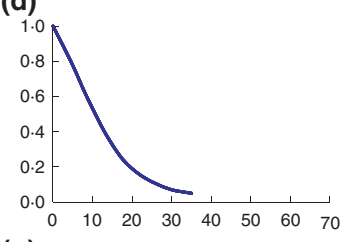

(g)

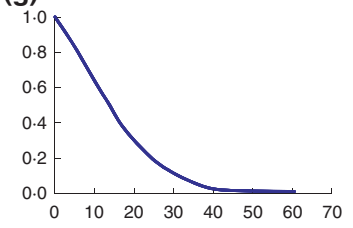

(j)

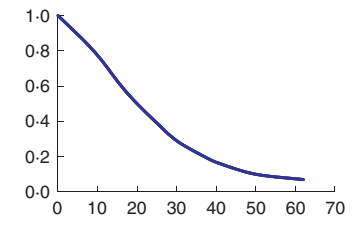

Fig. 1. Cumulative forms of fire frequency distributions for 10 protected areas in the fynbos biome. The areas are: $\mathrm{a}=$ Table Mountain; $\mathrm{b}=$ Kogelberg; $\mathrm{c}=$ Riviersonderend; $\mathrm{d}=$ Nuweberg; $\mathrm{e}=$ Waterval; $\mathrm{f}=$ Limietberg; $\mathrm{g}=$ Cederberg; $\mathrm{h}=$ Outeniqua; $\mathrm{i}=$ Kammanassie; $\mathrm{j}=$ Swartberg. 
Table 4. Features of the fire history over 33-37 years of 10 protected areas in the fynbos biome

\begin{tabular}{lrrll}
\hline & $\begin{array}{l}\text { Total area } \\
\text { burnt in } \\
\text { all fires } \\
\text { (ha) }\end{array}$ & $\begin{array}{l}\text { Number } \\
\text { of fires }\end{array}$ & $\begin{array}{l}\text { Median fire } \\
\text { return } \\
\text { (years) }\end{array}$ & $\begin{array}{l}\text { \% of area } \\
\text { burnt in } \\
\text { prescribed } \\
\text { fires }\end{array}$ \\
\hline Protected area & 45757 & 373 & 12 & $14 \cdot 6$ \\
Kable Mountain & 41826 & 98 & 16 & $14 \cdot 9$ \\
Riviersonderend & 124931 & 110 & 10 & $32 \cdot 4$ \\
Nuweberg & 114585 & 195 & 11 & $6 \cdot 5$ \\
Waterval & 192064 & 182 & 12 & $4 \cdot 6$ \\
Limietberg & 229621 & 220 & 10 & $11 \cdot 2$ \\
Cedarberg & 241749 & 115 & 13 & $11 \cdot 6$ \\
Outeniqua & 80867 & 162 & 18 & $26 \cdot 1$ \\
Kamanassie & 86657 & 75 & 11 & $4 \cdot 2$ \\
Swartberg & 157878 & 159 & 21 & 0 \\
\hline
\end{tabular}

See Table 1 for extent of protected areas and the length of the fire record.

Mean fire return intervals ranged from 10 to 13 years in 7 of 10 protected areas. Three of the areas had longer return periods of 16-21 years (Table 4). A relatively small area (between $4.6 \%$ and $32.4 \%$ of the area of all fires) burnt in prescribed burns, suggesting that wildfires had a greater influence on fire return intervals than prescribed burning. The Swartberg Nature Reserve was managed as a "naturalburning zone' where fires were not prescribed, and fires came about largely as a result of lightning (Seydack, Bekker \& Marshall 2007).

\section{FIRE SEASONALITY AND SIZE}

Although fires occurred in every month of the year, the pattern is seasonal, with the majority of area burnt from November to March (Fig. 2). The exception is the eastern coastal zone, where a sizable proportion of fires took place in winter (June-
August), reflecting the climatic conditions in the zone (Table 2). A relatively small proportion of the area burnt in prescribed burns; in the western zones, many of these were between April and September (Fig. 2), despite a policy that called for burning between November and March for ecological reasons (van Wilgen et al. 1992). This reflects the propensity of managers to place safety before ecological considerations.

Large fires ( $>10000$ ha) were rare, with only 21 of 1689 fires falling into this category (Fig. 3). Most of the area burnt in 265 fires of between 1000 and 10000 ha. The three largest fires on record were 50897,30667 and 28394 ha. These areas represent the extent of the fires within the boundaries of the protected areas; the total areas that burnt in these large fires (including areas outside of the protected areas) were 58 528, 32315 and 35503 ha, respectively.

\section{WEATHER AND FIRE OCCURRENCE}

Only 703 of the fires on record had an exact date (year, month and day or days), and could thus be associated with a FDI. Fires took place under a wide range of weather conditions, but fires $>5000$ ha were always associated with a FDI of $>10$ (moderate-high), and fires $>10000$ ha were associated with a FDI of $>20$ (high to very high, Fig. 4). The inland zones also experienced a more severe fire climate than the coastal zones, with three times as many days being classified as either high or very high in terms of fire danger (Table 5). Although large fires are associated with high to very high fire danger, fire return periods were similar between the inland and the western and south-western coastal zones, suggesting that additional weather-related opportunities for fire in the inland zones did not result in a higher incidence of fire. This in turn suggests that the frequency of ignition sources limits the overall incidence of fire.
Fig. 2. Proportion of fynbos vegetation burnt in each month between 1970 and 2007 in five climate zones in the fynbos biome, South Africa. Un-shaded portions denote prescribed burns and shaded portions denote all other fires.
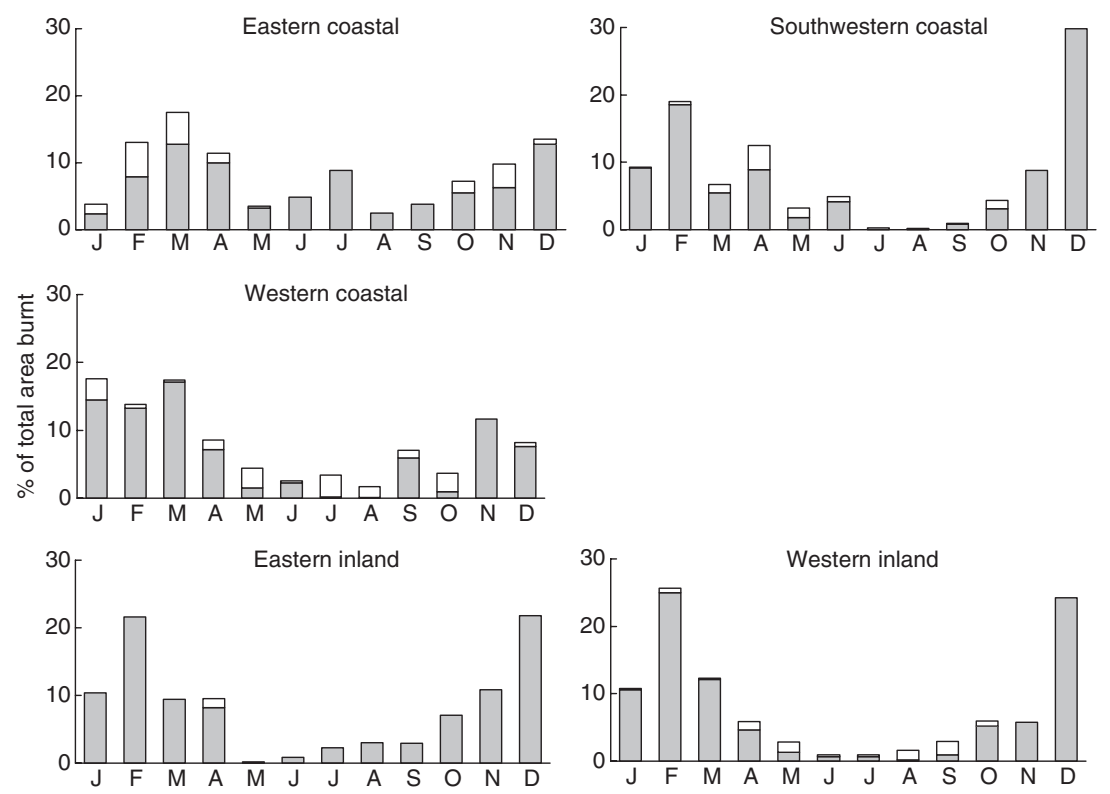

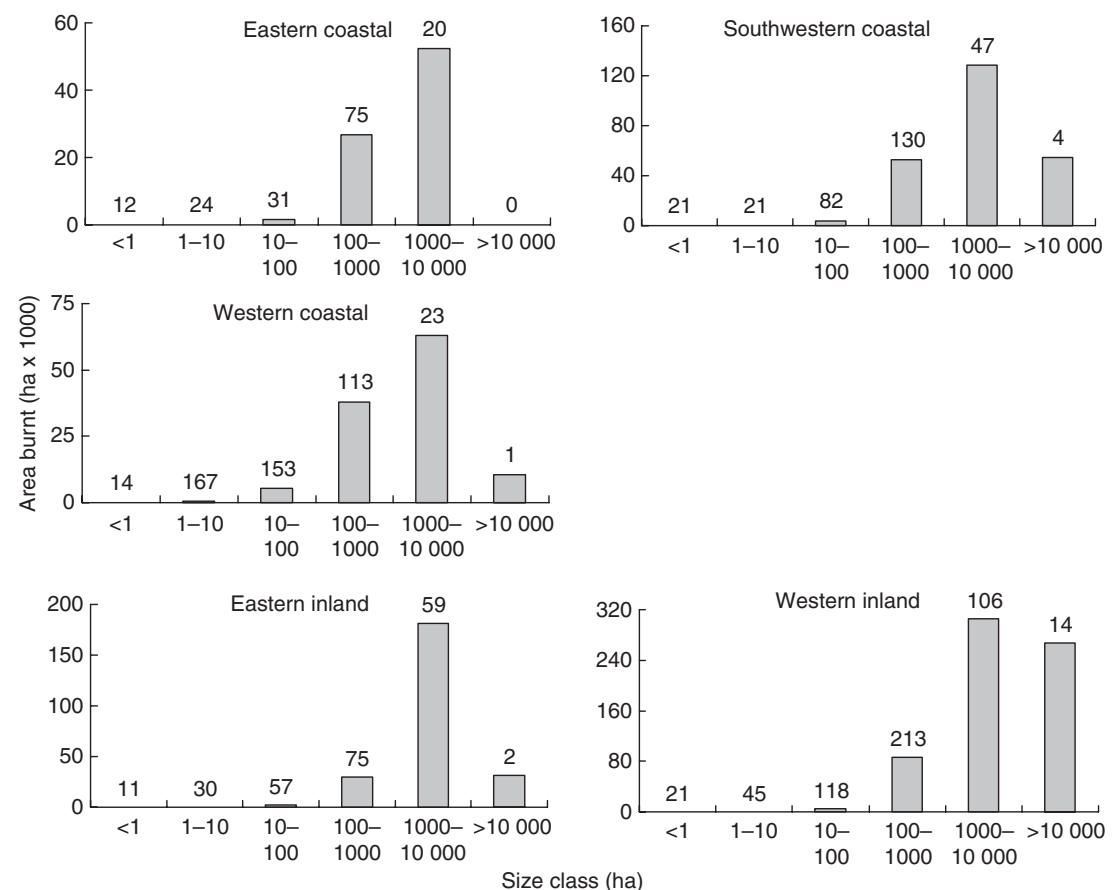

Fig. 3. Area of fynbos vegetation burnt in fires of different size between 1970 and 2007 in five climate zones in the fynbos biome, South Africa. The number of fires in each size class is given above bars. Note that scales for area differ between zones.

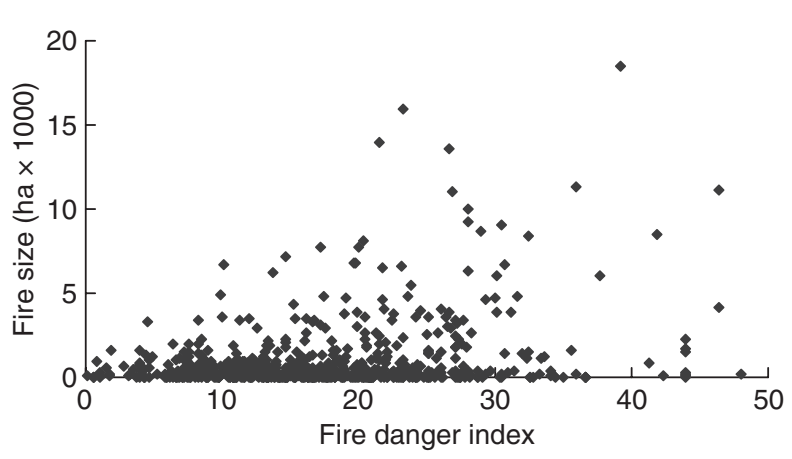

Fig. 4. The relationship between fire size $(n=703)$ in fynbos vegetation burnt between 1970 and 2007 in the fynbos biome, South Africa, and the maximum daily fire danger index prevailing during each fire.

\section{Discussion}

\section{FACTORS INFLUENCING FIRE RETURN INTERVALS}

Fire return intervals are determined by how often the three necessary conditions for fire (the presence of sufficient continuous fuel beds; hot, dry weather and a source of ignition) co-occur at the same place over time. The time required to accumulate sufficient fuel (post-fire age) is therefore an important determinant of fire return intervals. Fire managers in the latter half of the 20th century (including those responsible for managing fynbos) assumed that exclusion of fire through fire suppression would lead to an accumulation of fuel, leading in turn to large, uncontrollable wildfires. Prescribed burning with the goal of fuel reduction and fragmentation was often proposed as a means by which such large wildfires could be prevented. However, in recent years, the validity of these assumptions has increasingly been challenged in the Mediterranean-climate chaparral in California (e.g. Keeley, Fotheringham \& Morais 1999). In chaparral and most other fire-prone ecosystems, it has been found that rapid post-fire fuel accumulation rates frequently limit the effectiveness of prescribed fire in reducing wildfire risk to a short post-treatment period of 2-4 years (Fernandes \& Botelho 2003; Moritz et al. 2004), which is supported by our results. There is now evidence that the frequency of fires in Mediterranean-climate shrublands is strongly influenced by human population densities, which have the effect of increasing the frequency of ignitions (Syphard et al. 2009). This was seen as a significant threat to the integrity of these ecosystems.

Table 5. The percentage of days (from 1970 to 2007) falling within different fire danger categories in five fire climate zones in the fynbos biome

\begin{tabular}{llllll}
\hline & \multicolumn{2}{l}{ Fire climate zones } & & & \\
\cline { 2 - 6 } Fire danger rating & Western coastal & Western inland & South-western coastal & Eastern coastal & Eastern inland \\
\hline Low & $33 \cdot 3$ & $24 \cdot 2$ & $47 \cdot 3$ & $66 \cdot 7$ & $13 \cdot 6$ \\
Moderate & $47 \cdot 9$ & $40 \cdot 9$ & $41 \cdot 3$ & $27 \cdot 8$ & $50 \cdot 6$ \\
High & $17 \cdot 0$ & $31 \cdot 0$ & $10 \cdot 1$ & $4 \cdot 9$ & $31 \cdot 5$ \\
Very high & $1 \cdot 8$ & $3 \cdot 9$ & $1 \cdot 3$ & $0 \cdot 6$ & $4 \cdot 3$ \\
\hline
\end{tabular}

The ratings are ranges of the McArthur Forest Fire Danger Index, as follows: low (0-5); moderate (5-12); high (13-24) and very high $(>25)$. 
In our study, inland zones experienced a more severe fire climate than the coastal zones (Table 5), but this was not consistently reflected in similar differences in fire return intervals over more than three decades, suggesting that ignition opportunities, rather than fuel or weather, limited the occurrence of wildfires. In fynbos vegetation, the presence of fuel seems not to limit fires, except in the first few years post-fire, and median fire return intervals in this study were between 10 and 13 years in 7 of 10 areas. The exceptions were the Swartberg, Outeniqua and Kogelberg. The Swartberg (median fire return interval of 21 years) has relatively low rainfall over much of its area, and correspondingly lower rates of fuel accumulation which result in longer inter-fire periods (Seydack et al. 2007). The case of the Outeniqua (with a median fire return interval of 18 years) may be explained by a relatively mild fire climate. This area had the highest proportion of days $(66 \%)$ in the low fire danger category (Table 5), which could reduce the likelihood of cooccurring suitable weather and ignition opportunities in the eastern coastal zone. In the Kogelberg, the relatively long median fire return interval of 16 years could be explained by less ignition opportunities, as public access to the area was denied between 1968 and 1992.

\section{SELECTING FIRE RETURN INTERVALS FOR CONSERVATION}

The choice of an interval between fires that will benefit the majority of species in fire-prone ecosystems is usually based on an understanding of their reproductive biology. Important factors to consider include the ability to sprout after fire, the maturity age for species that reproduce by means of seed and dispersal abilities (Noble \& Slatyer 1980). The selection of the minimum post-fire age at which to burn fynbos has been guided by the interval between fires that would allow at least $50 \%$ of individuals in a population of the slowest-maturing of the obligate reseeding plant species to have flowered and set seed for at least three successive seasons (Kruger \& Lamb 1979; van Wilgen et al. 1992). Application of this rule normally suggests a minimum inter-fire period of $c$. 12-15 years between fires. Our analysis shows that median return intervals are between 10 and 13 years in 7 of 10 areas (Table 4), which means that half of the area burns at a post-fire age of $<10$ 13 years (Fig. 1), although not necessarily repeatedly.

It is well-documented that repeated frequent burning (at intervals of 4 years) can eliminate important overstorey shrubs in fynbos (van Wilgen 1981, 1982). It has also been shown that increased fire frequency favoured sprouting species in the Swartberg, and that increases in sprouters were associated with decreases in non-sprouting plant diversity (Vlok \& Yeaton 1999). Concerns about the conservation of fynbos shrublands in the latter half of the 20th century focused on the perception that fire was not frequent enough (Bond 1980; van Wilgen 1982). Our analysis does not provide support for this concern, as the areas assessed here experience regular fires, despite the relatively low proportion of the area that burnt in prescribed burns. On the contrary, there is now evidence that fires may be increasing in frequency, both in fynbos (Forsyth \& van Wilgen
2008) and other Mediterranean-climate ecosystems (Syphard et al. 2009). Rather than a focus on regular 'rejuvenation' as soon as the vegetation matures, prescribed burning should possibly be used only when the vegetation approaches senescence, which suggests the adoption of a much longer target period between prescribed burns. Our finding that fire return intervals are not reliant on long periods that allow for fuel accumulation would further lend support to this suggestion, as regular burning will not necessarily prevent large wildfires, which are more dependant on weather and sources of ignition than they are on fuel accumulation.

\section{FIRE REGIMES AND INVASIVE ALIEN PLANTS}

Alien plant invasions can, among other effects, change fuel properties, which can in turn affect fire behaviour and, ultimately, alter fire regime characteristics such as frequency, intensity, extent, type and seasonality of fire (Brooks et al. 2004). In Mediterranean-climate ecosystems, invasive alien plants differ in their effects on vegetation structure and fire regimes. Chaparral ecosystems are invaded mainly by alien grasses, whereas in fynbos the important invasive species are trees and shrubs.

Alien grasses in chaparral grow relatively rapidly when compared with the native shrubs, and can decrease the intervals between fires due to rapid fuel production (Keeley 2001). Fynbos, however, is invaded by pines (Pinus species) and hakeas (Hakea species). These woody invaders increase fuel loads and the intensity of fires (van Wilgen \& Richardson 1985), leading to severe erosion after fires (Scott \& vanWyk 1990). The negative effects of invasive alien trees in fynbos ecosystems on fire intensity, erosion and biodiversity make them the single largest threat to the conservation of extant fynbos areas (Van Wilgen 2009).

Prescribed burning forms an important component of the control of invasive pines and hakeas (Holmes et al. 2000). There are many factors that contribute to the relatively low proportion of area that burns in prescribed burns in the fynbos, the most important of which include a narrow seasonal window of opportunity to conduct ecologically acceptable prescribed burns safely, a lack of funding, the need to incorporate the pre-fire treatment of invasive alien plants, and growing concerns about the safety of prescribed burning and legal liability in cases where prescribed burns escaped (Van Wilgen 2009). Given these constraints, it would seem prudent to prioritize the limited opportunities for prescribed burning to areas where fires are needed for the treatment of invasive pines and hakeas. Our analysis suggests that this would be acceptable as prescribed burns would not be needed to reduce fuel loads and fire hazard, and only rarely to rejuvenate the vegetation.

\section{MANAGEMENT IMPLICATIONS}

Our analysis suggests that prescribed burning is either, by and large, not required (in the case of providing sufficient fire for regeneration), or ineffective (in the case of reducing the incidence of wildfires). In terms of the conservation of fynbos ecosystems, the largest threats will come not from the suppression 
or containment of fire, but from increasing sources of ignition that will lead to an increase in the frequency of fires. Associated with this is the risk that the spread of fire-adapted alien trees and shrubs (which already constitute a significant threat) will be further increased by more frequent fire. These problems are very similar to those experienced in California, where increasing human populations and alien plant invasions are changing fire regimes. Agencies charged with the conservation of fynbos shrublands should monitor fire return intervals, and take steps to protect areas that are in danger of burning too frequently. In addition, they should prioritize the use of limited funds, and limited opportunities to conduct safe prescribed burns, to areas where they can address the control of invasive alien trees and shrubs.

\section{Acknowledgements}

We thank Cape Action for People and the Environment and the CSIR for funding this work, and the Western Cape Nature Conservation Board and South African National Parks, for access to fire data.

\section{References}

Biswell, H.H. (1989) Prescribed Burning in California Wildlands Vegetation Management. University of California Press, Berkley.

Bond, W.J. (1980) Fire and senescent fynbos in the Swartberg, southern Cape. South African Forestry Journal, 114, 68-74.

Bond, W.J. \& Keeley, J.E. (2005) Fire as a global 'herbivore': the ecology and evolution of flammable ecosystems. Trends in Ecology and Evolution, 20, 387-394.

Bond, W.J. \& van Wilgen, B.W. (1996) Fire and Plants. Chapman \& Hall, London

Brooks, M.L., D’Antonio, C.M., Richardson, D.M., Grace, J.B., Keeley, J.E., Ditomaso, J.M., Hobbs, R.J., Pellant, M. \& Pyke, D. (2004) Effects of invasive alien plants on fire regimes. BioScience, 54, 677-688.

Cowling, R.M., Richardson, D.M. \& Mustart, P.J. (1997) Fynbos. Vegetation of Southern Africa (eds R.M. Cowling, D.M. Richardson \& S.M. Pierce), pp. 99-130. Cambridge University Press, Cambridge.

De Klerk, H. (2008) A pragmatic assessment of the usefulness of the MODIS (Terra andAqua) 1-km active fire (MOD14A2 and MYD14A2) products for mapping fires in the fynbos biome. International Journal of Wildland Fire, 17 166-178.

Fernandes, P.M. \& Botelho, H.S. (2003) A review of prescribed burning effectiveness in fire hazard reduction. International Journal of Wildland Fire, 12 $117-128$.

Forsyth, G.G. \& van Wilgen, B.W. (2008) The recent fire history of the Table Mountain National Park, and implications for fire management. Koedoe, 50, 3-9.

Gill, A.M. (1975) Fire and the Australian flora: a review. Australian Forestry, 38, 4-25.

Gill, A.M., Bradstock, R.A. \& Williams, J.E.. (2002), Fire regimes and biodiversity: legacy and vision. Flammable Australia: The Fire Regimes and Biodiversity of a Continent (eds R.A. Bradstock, J.E. Williams \& A.M. Gill), pp 429-446. Cambridge University Press, Cambridge.

Goldblatt, P. \& Manning, J. (2002) Plant diversity of the Cape region of South Africa. Annals of the Missouri Botanical Garden, 89, 281-302.

Holmes, P.M., Richardson, D.M., van Wilgen, B.W. \& Gelderblom, C. (2000) The recovery of South African fynbos vegetation following alien tree clearing and fire: implications for restoration. Austral Ecology, 25, 631-639.

Keeley, J.E. (2001) Fire and invasive species in Mediterranean-climate ecosystems of California. Proceedings of the Invasive Plant Workshop: The Role of Fire in the Control and Spread of Invasive Species (eds K.E.M. Galley \& T.P. Wilson), pp 81-94. Tall Timbers Research Station, Tallahassee, FL.

Keeley, J.E. \& Fotheringham, C.J. (2006) Wildfire management on a humandominated landscape: California chaparral wildfires. The Wildfire Reader A Century of Failed Forest Policy (ed G. Wuerthner), pp 116-131. Island Press, Washington.

Keeley, J.E., Fotheringham, C.J. \& Morais, M. (1999) Re-examining fire suppression impacts on brushland fire regimes. Science, 284, 1829-1832.
Keith, D.A., Williams, J.E. \& Woinarski, J.C.Z. (2002) Fire management and biodiversity conservation: key approaches and principles. Flammable Australia: The Fire Regimes and Biodiversity of a Continent (eds R.A. Bradstock, J.E. Williams \& A.M. Gill), pp 401-425, Cambridge University Press, Cambridge.

Kruger, F.J. \& Lamb, A.J. (1979) Conservation of the Kogelberg State Forest. Preliminary Assessment of the Effects of Management From 1967 to 1978. Report 79-02. Jonkershoek Forestry Research Centre, Stellenbosch.

Le Maitre, D.C., Versfeld, D.B. \& Chapman, R.A. (2000) The impact of invading alien plants on surface water resources in South Africa: a preliminary assessment. Water $S A, \mathbf{2 6}, 397-408$.

Moritz, M.A., Keeley, J.E., Johnson, E.A. \& Schaffner, A.A. (2004) Testing a basic assumption of shrubland fire management: does the hazard of burning increase with the age of fuels? Frontiers in Ecology and the Environment, 2, $67-72$.

Mucina, L. \& Rutherford, M.C. (2006) The Vegetation of South Africa, Lesotho and Swaziland. Strelitzia 19. South African National Biodiversity Institute, Pretoria.

Noble, I.R. \& Slatyer, R.O. (1980) The use of vital attributes to predict successional changes in plant communities subject to recurrent disturbances. Vegetatio, 43, 5-21.

Noble, I.R., Gill, A.M. \& Bary, G.A.V. (1980) McArthur's fire danger meters expressed as equations. Austral Ecology, 5, 201-203.

Parr, C.L. \& Andersen, A.N. (2006) Patch mosaic burning for biodiversity conservation: a critique of the pyrodiversity paradigm. Conservation Biology, 20, $1610-1619$

Polakow, D. \& Dunne, T. (1999) Modelling fire-return interval T: stochasticity and censoring in the two-parameter Weibull model. Ecological Modelling, 121, 79-102.

Richardson, D.M., van Wilgen, B.W., Le Maitre, D.C., Higgins, K.B. \& Forsyth, G.G. (1994) A computer-based system for fire management in the mountains of the Cape Province, South Africa. International Journal of Wildland Fire, 4, 17-32.

Scott, D.F. \& vanWyk, D.B. (1990) The effects of wildfire on soil wettability and hydrological behaviour of an afforested catchment. Journal of Hydrology, 121, 239-256.

Seydack, A.H.W., Bekker, S.J. \& Marshall, A.H. (2007) Shrubland fire regime scenarios in the Swartberg Mountain Range, South Africa: implications for fire management. International Journal of Wildland Fire, 16, 81-95.

Smithers, J.C. \& Schulze, R.E. (2000) Development and Evaluation of Techniques for Estimating Short Duration Design Rainfall in South Africa. Report 681/1/00. Water Research Commission, Pretoria. 356 pp.

Syphard, A.D., Radeloff, V.C., Hawbaker, T.J. \& Stewart, S.I. (2009) Conservation threats due to human-caused increases in fire frequency in Mediterranean-climate ecosystems. Conservation Biology, 23, 758-769.

Van Wilgen, B.W. (2009) The evolution of fire and invasive alien plant management practices in fynbos. South African Journal of Science, 105, 335-342.

Van Wilgen, B.W. (1981) Some effects of fire frequency on fynbos plant community composition and structure at Jonkershoek, Stellenbosch. South African Forestry Journal, 118, 42-55.

Van Wilgen, B.W. (1982) Some effects of post-fire age on the above-ground biomass of fynbos (macchia) vegetation in South Africa. Journal of Ecology, 70, 217.

Van Wilgen, B.W. (1984) Fire climates in the southern and western Cape Province and their potential use in fire control and management. South African Journal of Science, $\mathbf{8 0}, 358$

Van Wilgen, B.W. \& Richardson, D.M. (1985) The effect of alien shrub invasions on vegetation structure and fire behaviour in South African fynbos shrublands: a simulation study. Journal of Applied Ecology, 22, 955.

Van Wilgen, B.W. \& van Hensbergen, H.J. (1992) Fuel properties of vegetation in Swartboskloof. Fire in South African Mountain Fynbos: Species, Community and Ecosystem Response in Swartboskloof (eds B.W. van Wilgen, D.M. Richardson, F.J. Kruger \& H.J. van Hensbergen), pp 37-53. Springer-Verlag, Heidelberg.

Van Wilgen, B.W., Bond, W.J. \& Richardson, D.M.(1992) Ecosystem management. The Ecology of Fynbos: Nutrients, Fire and Diversity (ed R.M. Cowling), pp. 345-371. Oxford University Press, Cape Town.

Van Wilgen, B.W., Govender, N., Biggs, H.C., Ntsala, D. \& Funda, X.N. (2004) Response of savanna fire regimes to changing fire management policies in a large African national park. Conservation Biology, 18, 1533-1540.

Vlok, J.H.J. \& Yeaton, R.I. (1999) The effect of overstorey proteas on plant species richness in South African mountain fynbos. Diversity and Distributions, 5, 213-222.

Received 24 September 2009; accepted 3 March 2010

Handling Editor: Phil Hulme 